\title{
The tragedy of responsibility in High Asia: modernizing traditional pastoral practices and preserving modernist worldviews
}

Hermann Kreutzmann

Correspondence:

h.kreutzmann@fu-berlin.de

Centre for Development Studies, Geographic Sciences, Freie Universitaet Berlin, Malteserstr. 74-100, House K, Berlin 12249, Germany

\section{Springer}

\begin{abstract}
The nomadism/pastoralism debate has always been closely connected to discourses about modernization theories whenever development issues were at stake. While the mainstream debates have changed since stage models apparently became outdated, it is surprising that the Chinese development model seems to adhere to classical modernization theory. Consequently, it appears worthwhile to consider present challenges in the pastoral sector first from the Chinese perspective and, second, in comparison with the situation in neighbouring countries.

The discussion reveals that the Chinese model is quite different from neighbouring countries' practices and is embedded in an authoritarian approach that suggests similarities with the implementation of a development model during the collectivization phases in the Soviet Union and the People's Republic of China, when Stalinist- and Mao Zedong-inspired models were implemented under autonomy and sedentarization regimes. Nevertheless, the present context is quite different because ecological degradation of pastures and the non-existent closure of the development gap between affluent urbanites and remote farmers and pastoralists have been addressed by implementing the present resettlement programmes.

In China's pastoralism regions, the tragedy of responsibility is related to top-down approaches without adequate participation of stakeholders. In neighbouring countries, pastoralists tend to complain about negligence by state authorities, nonbinding regulations and arbitrariness by powerful actors. Countries such as India and Pakistan are still reworking their colonial legacies and trying to adapt pasture legislation to the demands of rangeland management and nature protection.
\end{abstract}

Keywords: Resettlement, Transformation, Pastoral practices, Pastoral township, Rangeland degradation, Modernist adaptation

\section{Background}

The appropriation or conversion of land that was formerly utilized by pastoral strategies can be discussed in relation to neoliberal conquests, inscribing environments and shifting social scapes. All vantage points are related to pressing issues and contemporary debates; currently, land-grabbing and resettlement schemes could be named. Both are responses to external innovations and interests in former or current peripheral areas that have come into focus in an arena of shrinking space. Investments in agricultural and industrial enterprises, exploitation of natural resources and nature protection

(c) 2013 Kreutzmann; licensee Springer. This is an Open Access article distributed under the terms of the Creative Commons Attribution License (http://creativecommons.org/licenses/by/2.0), which permits unrestricted use, distribution, and reproduction in any medium, provided the original work is properly cited. 
are the fields of action. The thematic thrust can be seen as addressing transformations that can be attributed to the agency of development. If we perceive agency as "... the network of institutions and actors that through their actions and interactions 'produce' development" (Kothari and Minogue 2002), then the focus becomes even more obvious.

Development inspired by modernization efforts seems to prepare the ground for neoliberal conquests. The prefix 'neo' suggests something new. The new sometimes only disguises the established and inherited. By giving it a new expression, a new term is constructed, embedded in a different setting. What has changed in the meantime, and when did the shift occur? I would argue that conventional views essentially advocated by modernizers considered that pastoralism needed to be abolished, as it was classified as a stage of civilization to be transcended in order to reach a higher level of development or as a 'stagnant' mode of production $c f$. (Bobek 1959; Gellner 1973; Herzog 1963; Khazanov 1981; Markov 1981). The benchmark for development was basically income-related and/or attributed to a certain degree of modernity. 'Modernist teleological accounts' (Sheppard 2012, p. 62) have been carrying forward stage theories that go back to nineteenth century thinking and have influenced economic modernization theories since. Their paramount pretence has prevailed in more contexts than often acknowledged. Social mobility - as opposed to spatial mobility - plays an important role in these concepts of development. Modernization theory has been - and has not ceased to be the conceptual background that agrees well with neoliberal conquests. The twentieth century sets the stage for the challenges of the twenty-first.

In this context, global approaches such as those of Herzog (1963) and Markov (1978) promoting sedentarization and modernization of rural societies have been ubiquitous phenomena independent of ideological and regional contexts (Dyson-Hudson 1972; Kaufmann 2009; Khazanov 2005; Montero et al. 2009; Salzman and Galaty 1990). The twentieth century experienced a variety of concepts to settle nomads and adapt their lifestyles to modern expectations and perceptions.

'When nomads settle' (Salzman 1980), then obviously the 'future of pastoral peoples'(Galaty et al. 1981) is at stake and has to come into focus. Is sedentarization the result of an inevitable modernization process or an adaptation to changed frame conditions? Does settlement in itself form a crisis of pastoralism, or is this just another approach by state authorities and development agents to cope with societal and economic challenges?

Creation of permanent settlements has often been the vivid expression of an ideology-driven approach that aimed '... at reducing flexibility in favour of concentration and rootedness. Modernization theory translated into development practice captured all elements of pastoral life and tried to optimise breeding techniques, pasture utilisation, transport of animals and products, and related processing concepts to increase the value of livestock products.' (Kreutzmann and Schütte 2011, p. 104). The antagonism is symbolically highlighted in the meeting of the mobile and the settled. Both ascriptions refer to other dichotomies: tradition and modernity, weak and powerful, rural and urban, the slow and the fast mover.

These terms are heavily loaded and have structured the debate. The opposition between mobile and settled often disguises fundamental differences in the perception of what decision makers think development should look like and should achieve. 
It seems that tradition and modernization may be the strongest opposition. In the following, I shall focus on the modernization of traditional practices and tendencies to preserve modernization as a key concept of development.

\section{Effects of modernisation on pastoral practices}

Modernization theory as promoted in the West and in the East in the aftermath of World War II and within the framework of early post-colonial 'development decades' was inspired by the aim of changing people's lifestyles to attain higher levels of production and welfare. Nomadism was one of the main targets; sedentarization was one of the visible attestations that change had taken place. Capitalist development experts and communist central planners shared the same principles when it came to the settling of nomads. Political stability was aimed for, and modernity was the socio-economic rationale. The results are well known to us and do not need to be repeated in greater detail. The more surprising is the fact that old blueprints have been reanimated as we shall see below.

The settling of nomads resulted in an early version of land grabbing, expropriation of inherited resource access and resource conversion, albeit it took place mainly within the boundaries of nation states and promoted input-demanding forms of agriculture in order to increase material output. For example, collectivization in its Soviet and Chinese interpretations and expressions has significantly altered and shaped Central Asian pastoral practices.

The conversion of pastures into arable land has caused one of the most significant environmental impacts of land degradation on Earth. In the Kazakh steppe, for example, 25 million hectares of pasture land were converted into arable land within a span of only seven years (Succow 2004, p. 31). The process of degradation is mostly irreversible; half of this land has fallen fallow in the meantime. Arable land was not expected to revert to pasture again. The Kazakh example is a good case in point because, first of all, collectivization initiated an exodus of millions of Kazakh nomads and inflicted heavy losses of life; then, a downfall in animal production required a number of years to be compensated. The number of sheep declined from its peak in 1928 to less than one fifth by the mid-1930s when collectivization reached full swing. It took until 1958 to offset this loss and reach the same animal levels as those 30 years earlier. In a second major step, the steppe lands were then converted into agricultural fields which intensified the effects of the disastrous planning and implementation of a multifaceted modernization package (Dakhshleiger 1978). From 1954 onwards, the area of agricultural lands used for grain and fodder production in Kazakhstan increased fivefold within less than five years; (for a detailed analysis and graphic description, see Alimaev and Behnke (2008), Giese (1982, 1983) and Svanberg (1989)). Shortly after these transformations of the agro-pastoral environment in 1962, Kazakhs left China for the Soviet Union, a form of reverse migration that has found a new momentum in recent years (Cerny 2010). Nevertheless, these external interventions with far-reaching consequences are not unidirectional effects in terms of pasture use and cross-border migration.

On the southern fringes of Central Asia, similar processes took place with varied expressions and changing efficiency. Pastoralists were 'developed' into farmers. From Afghanistan to Bhutan, modernization strategies have resulted in shrinking numbers of 
pastoralists and numerous programmes and packages to modernize agriculture since the last quarter of the twentieth century. Input-driven forms of development aimed to increase productivity. In both areas, perceptions of modernization did not differ significantly. The process of settlement continued, and in the true spirit of modernization theory, the convergence of lifestyles was envisaged, meaning the settling-down of all people.

The end of the Cold War seemed to provide a new impetus and drive for pastoralism studies. The debate on human-environmental relations again focused on adaptive strategies for the utilization of marginal resources, leading eventually to a shift away from acceptance of pastoralism as a niche production system, when climate change and biodiversity paradigms became stronger (Ehlers and Kreutzmann 2000; Nori and Davies 2007; Roe et al. 1998). A second area of attention is connected to governance and (in)security issues when the appropriation of space is discussed as part of a civilization and modernization project in the age of globalization (e.g. Gertel and Breuer 2007; Kreutzmann et al. 2011a, b; Kreutzmann 2012b; Scott 2009). Both perspectives implicitly contain a critique of external interventions by predominant actors and powerful stakeholders as well as a repudiation of capitalist and communist concepts of modernization.

\section{Revival of modernization theory and practice: The Chinese model}

The challenge originating from these new perspectives opens up a debate that needs to regionalize its attention. The examples presented here are derived from the present author's own fieldwork and research in High Asia. All aspects that have been mentioned so far can easily be observed in Chinese strategies in the pastoral realm - the interference of central authorities in treating pastoral people, decreeing resource utilization strategies and implementing 'modern' lifestyles.

Before exemplifying the Chinese model, a few remarks on the wider spectrum are required: Four responses need to be highlighted for High Asia when we address recent developments.

1. In Afghanistan, processes of re-nomadization are observed despite the high prevalence of land mines, continuing and even growing insecurity and poor governance (Kreutzmann and Schütte 2011; Schütte 2012; Tapper 2008). The last named factor puts the effectiveness of legislation such as the new pasture law into doubt.

2. In post-Soviet societies, various kinds of adaptation strategies are employed, and pastoral practices are part of a privatization drive. New land and pasture laws have been implemented in recent years ( $c f$. Baibagushev 2011; Doerre 2012; Kerven et al. 2012; Kraudzun 2012; Robinson and Whitton 2010; Schmidt and Doerre 2011;

Steimann 2012; Vanselow et al. 2012). Successful so-called new breeders use the opportunities given and fill the power vacuum.

3. South Asian countries are discussing the adaptation of their colonial legacies in pasture and forest legislation to the challenges of climate change and international conventions (cf. Inam-ur-Rahim and Beg 2011; Yi et al. 2012; Yi and Eklabya 2009). Pastoralists are grossly neglected as stakeholders and actors.

4. The Chinese government is taking an active role in interfering in all dimensions of pastoral practices ( $c f$. articles contributed by Chinese and international scholars in 
Kreutzmann et al. 2011a, b; Kreutzmann 2012a, b). After collectivization and deregulation, leading to the household responsibility system, a new approach has been followed.

In Chinese contexts, the concept of development is equivalent to modernization pragmatism ( $c f$. Cao 2009; Li 2010). In the early phase of the 'Great Leap Forward' (1958 to 1959), it was the campaign for 'take grain as the key link' (1958 to 1961). The conversion of pastures into agricultural fields was accompanied by the introduction of peoples' communes and production brigades in the farming and pasture sector. An additional impact can be attributed to the establishment of Production and Construction Corps, which entailed significant Han migration into Xinjiang and increased the pressure on valuable land and pasture resources (Gardner 2010; McMillen 2009; Millward 2009).

During the 'four modernizations' (1978 to 1996), the slogan changed to 'reform and opening-up' (1980) accompanied by de-collectivization and the revival of 'traditional' pastoral practices. Some observers perceived the distribution of communal livestock among households and the contracting of grassland user rights to them as the beginning of a deregulation and privatization in the pastoral sector (Goldstein and Beall 1991; Yan et al. 2005).

The recent development programmes of 'four constructions' (1996 to 2004) and the 'great development of the West' (since 2000) were preparing the ground for campaigns that aim at measures to 'restore pastures to grass' (2002) and 'grain to green' (2003) (cf. Banks et al. 2003; Foggin 2008, 2011; Gruschke 2008, 2012; Ho 2000; Miller 2000; Oi 1999; Yan et al. 2005; Yeh 2005; Kreutzmann 2011, overview table, pp. 214-216).

The present holistic Chinese state intervention justifies being termed as a renaissance of modernization pragmatism, if it had ever been dead. The straightforward and solitary approach to changing rural livelihoods in pastoral areas involves significant financial support from affluent coastal areas of China and is centrally planned. For Tibet see the overview in Kreutzmann (2011). The views of the Xinjiang authorities have been explicated by Xinchun (2011) in great detail. The recent announcement by former Prime Minister Weng Jiabao of the 'Twelfth Five-year-plan for the project of sedentarisation of nomads within China' seems to be the latest move to date in settling the remaining pastoralists in Inner Mongolia, Tibet, Xinjiang and adjacent areas. The Chinese text was put on the website of the Central People's Government of the People's Republic of China on 30 May 2012 (see http://www.gov.cn/ldhd/2012-05/30/content_2148928. $\mathrm{htm})$. The key concept is strongly linked to resettlement schemes that put the aspect of mobile versus settled in the forefront, but have wider implications regarding the reduction of the number of individuals active in pastoralism, the application of 'modern' techniques in animal breeding and health, the introduction of sophisticated pasture management through fencing, the introduction of economies of scale in herd management and marketing of livestock products.

In the true spirit of modernization theory, the future of pastoral people is not envisaged in settled circumstances only; here, the aim is the ultimate modernization: modernity can only be achieved in urban settings. Urbanization is perceived as a holistic process resulting in townships that provide adequate infrastructure and access to improved health facilities and educational institutions, thus enabling people to 
move upwards on the social ladder (Kreutzmann 2012a; Ptackova 2011). Consequently, townships are planned and built - in great style - as the nuclear cell of the 'resettlement schemes'. The cost of this endeavour is shared between central and regional government institutions, and there are also significant contributions from affluent cities in 'China proper' (Zhongguo ben bu). The measures aim at reducing the widening social gap between the industrialized zones and the remote agriculture-based areas.

The justification for such a severe move is from a rationale that identifies an ecological crisis as the prime driver and draws on the convergence principle in modernization theory. Degradation of pastures is taken as the signal for intervention in order to secure a valuable societal resource. In this perception, the pastoralists are the culprits responsible for overgrazing and need to be controlled ( $c f$. Harris 2010). In judging the value of the argument, we are confronted with two schools of thought: Is mobile pastoralism a well-adapted and sophisticated form of utilizing available and accessible marginal resources spread over wide spatial areas, or is mobile pastoralism prone to overgraze and destroy its own base? (see, e.g. Salzman and Galaty 1990; Scholz 2008). Ample evidence can be provided for both opinions, and the specific cases need to be scrutinized in order to arrive at a judgement. No general patterns can be generated. In several cases, it could be confirmed that shortage of labour and shepherds contributed to overgrazing in easily accessible locations, while other sites were abandoned. Adaptation due to changed societal conditions led to a differentiated pattern of overand under-utilization in adjacent pastures and contiguous grazing grounds ( $c f$. Doerre 2012; Kerven et al. 2012; Kraudzun 2012).

In China, the active planning process is supposed to reduce the utilization of natural pastures. International conventions on ecological protection, environment and development are quoted; compensation schemes such as payment for ecosystem services are being experimented with.

The second line of argument is just as important, as here the Chinese authorities take responsibility for raising the social status of pastoralists. This is implemented by geographical and social mobility. Settling the pastoralists in townships, as well as the introduction of centralized and regulated livestock breeding with less manpower, means that pastoralists and their children lose their familiar livelihoods and are expected to take up other occupations. The concentration of resettlement towns is accompanied by large-scale fencing schemes and new forms of pasture management.

Consequently, we find here a combination of strategies that originally could have been contradictory. Environmental protection theories were developed when modernization theories had failed to explain the world and had suggested unfeasible strategies. Sustainable development seemed to be an answer to this challenge under the premise of limited resources. In order to safeguard an optimal use of shrinking resources, a technological solution is favoured by introducing sophisticated agricultural practices and advanced technologies.

The Chinese authorities have rejuvenated the once-despised theories. Central planning authorities have created a cocktail package that serves the ultimate goal of modernization: modern life will take place only in urban contexts. Mobile pastoralists in remote rural locations are disturbing the central place system inspired by Walter Christaller's hierarchical order ( $c f$. Hall 2002). 
One could even go a step further and argue that the climate change debate has fostered a welcome collapse scenario and has promoted the urgent need for action. In the wake of adapting to climate change and mitigating its effects, social transformations are required that would have been difficult to implement in other circumstances.

The regional expressions introduced for non-Chinese High Asia have in common that we are observing a depopulation of the pastoral periphery while people are being concentrated in urban settlements. Our fieldwork in the Himalayan range has brought us to the remotest locations where nearly each and every household was linked to a migration scheme that could extend as far as to Southeast Asia, the Arabian Peninsula, and Europe. The Pamirian Mountains are devoid of a young pastoral workforce, as are other regions in Tajikistan and Kyrgyzstan. Are we facing a new drama?

\section{Drama of the commons or tragedy of responsibility?}

Pastoral practices have always adapted to new and threatening challenges and found an outlet to cope with mounting constraints. Therefore, the study of pastoralism provides us with insights into societies that are themselves structured by growing external demands and powerful interests. Societal and political changes can dominate over all kinds of climate and environmental changes if, for example, in the Chinese context we remember the losses of human lives during the 'Great leap forward' campaign which is estimated by Frank Dikötter (2010) in the order of 45 million persons.

In the context of this paper, the pastoral commons might be more narrowly defined than usual. The purpose is that the 'modernization' projects are not directed towards the settled habitations and the agricultural lands that are put under comparatively intensive use in crop farming, etc. and are regulated by communal and/or private ownership. Forests, pastures and rangelands are the target regions of the 'modernization project'. Here in the border zone of the ecumene where state and common property rights meet and where certain degrees of freedom of movement and usufruct utilization have been enjoyed over long periods, the present contest has found its arena.

Growing pressure on these commons has changed the attitude of policy makers and rangeland management planners who had long treated rangelands and their inhabitants as 'marginalised people in regions of neglect' (Kreutzmann 2012b, p. 329). The debate on the 'tragedy of the commons' triggered by Hardin (1968) has moved forward from its supposed starting point and gained significant pace in recent times. Land grabbing and expropriation of resources take place in an environment in which customary rights can easily be breached and community practices do not count. This state of affairs could well be noted as a 'drama of the commons' (Ostrom et al. 2002), a term that might more appropriately capture the situation. Even during the past decade, the pressure on land resources has continued to grow and led to an unequal positioning of interests. Hardin's solution for alleviating the 'tragedy of the commons' was the privatization of community land. Presently, we are observing an alternative form of privatization - the selling-off of vast tracts of agricultural land resources to powerful multinational state and private investors. In Africa and Asia, the state's permission to act is accordingly stimulating land grabbing and the expropriation of weak communities without any lobby. The drama of the commons is gaining further pace and appears to be a 'drama of responsibility' where the vital interests of rural people and communities are at stake and grossly neglected by their own governments. Land and rangelands 
- even remote pastures - have significantly appreciated in value. Neglect in our context is understood to express the notion of inadequate policies for pastoral communities and their stakes.

Talking about lack of responsibility is a double-edged issue. Up to the 1950s, pastoral areas were niches of evasion as Scott (2009) has shown so prominently in his book on the 'art of not being governed'. Researchers' sympathy for the periphery has transformed into administrators' greed. Bureaucrats have penetrated as far as the limits of the nation states, borderlands have been incorporated into mainstream societies, and spaces for evasion are shrinking tremendously (Kreutzmann 2013). We have seen the attention that post-revolution China has directed towards its pastoral communities during the past 60 years. China has a legacy of top-down interventions accompanied by all kinds of legislation, incentive packages and modernization programmes. But what have the neighbours done?

India and Pakistan have inherited rangeland management policies as a colonial legacy. Both started designing a national rangeland management policy rather late, as a side effect of new forest legislation. Their common point of reference was the 'Cattle Trespassers Act' of 1871 and the 'Forest Policy' of 1894. In Pakistan, a 'National Rangeland Policy' has been announced; a decision about the draft is still pending. India envisaged a paradigm shift with the 'National Forest Policy' (1988), in which rangelands played an important role, followed by the 2006 'National Environmental Policy'. In both countries, livestock production is supposed to be intensified to meet growing market demands in an arena of decreasing rangeland availability. Both are apparently failing to cope with the challenges. Similar statements could be made for Nepal. Only Bhutan nationalized its rangelands, made pastoralists - who are assumed to constitute a tenth of Bhutan's population - mainstream actors and made them eligible users within the framework of the 2007 'New Land Act of Bhutan'.

In Afghanistan, laws related to pasture management seem to have survived at least on paper. The 'Pasture Law' of 1970 codified the property rights of the government. The latest amendment was decreed under the Taliban in 2000. Currently, the pasture law is being redrafted under the guidance of international agencies to incorporate community-based pasture management systems. But the provisions of 1970 remain the official policy to date with little effect on pastoral practices and interferences by powerful actors (Kreutzmann and Schütte 2011).

A process of transition from state-owned property rights to leasehold and private and/or community-based pasture rights characterizes the state of affairs in the former Soviet Central Asian Republics. Kyrgyzstan recently introduced a new law on pastures, while Tajikistan has been following suit (Kraudzun 2012; Lim 2012; Robinson and Whitton 2010). Both countries acknowledge the importance of utilizing the natural potential; the so-called 'new breeders' are making ample use of their opportunities.

\section{Conclusion}

This brief characterization of policies and plans reveals a varied set of attitudes towards the management of the pastoral commons within the 'modernisation' ideology. The 'tragedy of responsibility' comes in different disguises. The designs of national policies are quite different and mainly governed by national agendas and international pressure. 
Whether they might be an adequate and appropriate instrument to address the challenges that pastoralist livelihoods are undergoing remains unanswered here.

The variations in different countries presented here show that pastoralists in China are becoming urbanized in a fashion that fulfils the dreams of a true believer in modernization theory. Not only is the mobile being subsumed into the settled, but at the same time the rural is becoming urban. The tradition of modernization thrives in China, while the development of the pastoral sector in other countries seems to be inspired by similar thoughts but driven by a less authoritarian spirit and supported by significantly less funds. The juxtaposition of ecological protection and developmental aspirations can obviously create an environment that seems to efficiently achieve societal transformations that were out of reach for early modernizers.

Modernization theory is alive and has always been alive; only its disguises and expressions have changed over time!

Competing interests

The author declares that he has no competing interests.

\section{Author's information}

HK is the Chair of Human Geography at the Institute of Geographic Sciences and Director of the Centre for Development Research at Freie Universität Berlin. His research focuses on issues such as migration, conflict, development, water utilisation, pastoralism and political geography in Central and South Asian contexts.

\section{Acknowledgements}

The paper is based on a keynote speech delivered at the international conference 'From nomadic empires to neoliberal conquests' in Hamburg in November 2011. Thanks are extended to the hosts of the conference, Jürgen Paul and Jörg Gertel. The presented thoughts resulted from experiences gained during the past three decades by conducting fieldwork in Central and South Asia. The fieldwork was generously supported in different programmes and capacities by the Deutsche Forschungsgemeinschaft (DFG), the Volkswagen Foundation and by InWEnt (now GIZ -

German Society for International Development). While the first two supported academic research in remote locations, the last named organised conferences and workshops where actors and stakeholders from the pastoralism world could voice their opinions and visions from which this paper has greatly benefited. Special thanks to the reviewers of the 'Pastoralism' journal and for valuable suggestions.

Received: 16 November 2012 Accepted: 18 February 2013

Published: 15 March 2013

\section{References}

Alimaev, II, and RH Behnke. 2008. Ideology, land tenure and livestock mobility in Kazakhstan. In Fragmentation in semiarid and arid landscapes: Consequences for human and natural systems, ed. KA Galvin, RS Reid, RH Behnke, and N Thompson Hobbs, 151-178. Dordrecht: Springer.

Baibagushev, E. 2011. Recent changes in pastoral systems. Case study on Kyrgyzstan. In Pastoralism and rangeland management in mountain areas in the context of climate and global change, ed. H Kreutzmann, K Abdulalishoev, L Zhaohui, and J Richter, 102-118. Bonn: Deutsche Gesellschaft für Internationale Zusammenarbeit.

Banks, T, C Richard, L Ping, and Z Yan. 2003. Community-based grassland management in western China: Rationale, pilot project experience, and policy implications. Mountain Research and Development 23(2): 132-140.

Bobek, H. 1959. Die Hauptstufen der Gesellschafts- und Wirtschaftsentfaltung in geographischer Sicht. Die Erde 90: 259-298.

Cao, F. 2009. Modernization theory and China's road to modernization. Chinese Studies in History 43(1): 7-16.

Cerny, A. 2010. Going where the grass is greener: China Kazaks and the Oralman immigration policy in Kazakhstan. Pastoralism 1(2): 218-247.

Dakhshleiger, GF. 1978. Settlement and traditional social institutions of the formerly nomadic Kazakh people. In The nomadic alternative, ed. W Weissleder, 361-3703. The Hague: Mouton.

Dikötter, F. 2010. Mao's great famine. The history of China's most devastating catastrophe 1958-62. London: Bloomsbury.

Doerre, A. 2012. Legal arrangements and pasture-related socio-ecological challenges in Kyrgyzstan. In Pastoral practices in High Asia. Agency of 'development' effected by modernisation, resettlement and transformation, ed. H Kreutzmann, 127-144. Dordrecht: Springer.

Dyson-Hudson, N. 1972. The study of nomads. In Perspectives on nomadism, ed. W Irons and N Dyson-Hudson, 2-29. Leiden: Brill.

Ehlers, E, and H Kreutzmann (eds.). 2000. High mountain pastoralism in northern Pakistan. Stuttgart: Steiner.

Foggin, MJ. 2008. Depopulating the Tibetan grasslands. National policies and perspectives for the future of Tibetan herders in Qinghai Province, China. Mountain Research and Development 28(1): 26-31.

Foggin, MJ. 2011. Rethinking 'ecological migration' and the value of cultural continuity-A response to Wang, Song, and Hu. Ambio: A Journal of the Human. Environment 40: 100-101. 
Galaty, JG, D Aronson, PC Salzman, and A Chouinard (eds.). 1981. The future of pastoral peoples. Ottawa: International Development Research Centre.

Gardner, B. 2010. The Uyghurs: Strangers in their own land. New York: Columbia University Press.

Gellner, E. 1973. Introduction: Approaches to nomadism. In The desert and the sown, ed. C Nelson, 1-9. Berkeley: Institute of International Studies University of California.

Gertel, J, and I Breuer (eds.). 2007. Pastoral Morocco. Globalizing scapes of mobility and insecurity. Wiesbaden: Reichert.

Giese, E. 1982. Seßhaftmachung der Nomaden in der Sowjetunion. In Nomadismus - Ein Entwicklungsproblem? ed. F Scholz and J Janzen, 219-231. Berlin: FU Berlin.

Giese, E. 1983. Nomaden in Kasachstan. Ihre Seßhaftwerdung und Einordnung in das Kolchos- und Sowchossystem. Geographische Rundschau 35: 575-588.

Goldstein, M, and CM Beall. 1991. Change and continuity in nomadic pastoralism on the western Tibetan Plateau. Nomadic Peoples 28: 105-122.

Gruschke, A. 2008. Nomads without pastures? Globalization, regionalization, and livelihood security of nomads and former nomads in Northern Khams. Journal of the International Association of Tibetan Studies 4: 1-40.

Gruschke, A. 2012. Nomadische Ressourcennutzung und Existenzsicherung im Umbruch. Die osttibetische Region Yushu (Qinghai, VR China). Wiesbaden: Reichert.

Hall, P. 2002. Christaller for a global age: Redrawing the urban hierarchy. In Stadt und Region: Dynamik von Lebenswelten, ed. A Mayr, M Meurer, and J Vogt, 110-128. Leipzig: Deutsche Gesellschaft für Geographie.

Hardin, G. 1968. The tragedy of the commons. Science 162 (13 December): 1243-1248.

Harris, RB. 2010. Rangeland degradation on the Qinghai-Tibetan plateau: A review of the evidence of its magnitude and causes. Journal of Arid Environments 74: 1-12.

Herzog, R. 1963. Seßhaftwerden von Nomaden. Köln, Opladen: Westdeutscher Verlag.

Ho, P. 2000. The clash over state and collective property: The making of the rangeland law. China Quarterly 16(1): 240263.

Inam-ur-Rahim, and A Beg. 2011. Production and marketing of livestock products in the Hindu Kush-KarakoramHimalaya. In Regional Workshop in Lhasa 2010. Pastoralism and rangeland management on the Tibetan Plateau in the context of climate and global change, ed. H Kreutzmann, Y Yong, and J Richter, 177-199. Bonn: GIZ.

Kaufmann, JC. 2009. The sediment of nomadism. History in Africa 36: 235-264.

Kerven, C, B Steimann, C Dear, and L Ashley. 2012. Researching the future of pastoralism in Central Asia's mountains: Examining development orthodoxies. Mountain Research and Development 32: 368-377.

Khazanov, AM. 1981. Myth and paradoxes of nomadism. Archives Européennes de Sociologie 22: 141-153.

Khazanov, AM. 2005. Nomads and cities in the Eurasian Steppe region and adjacent countries: A historical overview. In Shifts and drifts in nomad-sedentary relations, ed. S Leder and B Streck, 163-178. Wiesbaden: Reichert.

Kothari, U, and M Minogue (eds.). 2002. Development theory and practice. Critical perspectives. Hampshire: Palgrave.

Kraudzun, T. 2012. Livelihoods of the 'New Livestock Breeders' in the Eastern Pamirs of Tajikistan. In Pastoral practices in High Asia. Agency of 'development' effected by modernisation, resettlement and transformation, ed. H Kreutzmann, 89-107. Dordrecht: Springer.

Kreutzmann, H. 2011. Pastoral practices on the move. Recent transformations in mountain pastoralism on the Tibetan Plateau. In Regional Workshop in Lhasa 2010. Pastoralism and rangeland management on the Tibetan Plateau in the context of climate and global change, ed. H Kreutzmann, Y Yong, and J Richter, 200-224. Bonn: GIZ.

Kreutzmann, H. 2012a. Kirghiz in Little Kara Köl - The forces of modernisation in southern Xinjiang. In Pastoral practices in High Asia. Agency of 'development' effected by modernisation, resettlement and transformation, ed. $\mathrm{H}$ Kreutzmann, 109-125. Dordrecht: Springer.

Kreutzmann, H. 2012b. Pastoralism - A way forward or back? In Pastoral practices in High Asia. Agency of 'development' effected by modernisation, resettlement and transformation, ed. H Kreutzmann, 323-336. Dordrecht: Springer.

Kreutzmann, H. 2013. Boundary-making as a strategy for risk reduction in conflict-prone spaces. In The spatial dimension of risk. How geography shapes the emergence of riskscapes, ed. D Müller-Mahn, 154-171. Milton Park: Routledge.

Kreutzmann, H, and S Schütte. 2011. Contested commons - Multiple insecurities of pastoralists in North-Eastern Afghanistan. Erdkunde 65(2): 99-119.

Kreutzmann, H, K Abdulalishoev, L Zhaohui, and J Richter (eds.). 2011 a. Regional workshop in Khorog and Kashgar. Pastoralism and rangeland management in mountain areas in the context of climate and global change. Bonn: GIZ.

Kreutzmann, H, Y Yong, and J Richter (eds.). 2011 b. Regional Workshop in Lhasa 2010. Pastoralism and rangeland management on the Tibetan Plateau in the context of climate and global change. Bonn: GIZ.

Li, H. 2010. From revolution to modernization: The paradigmatic transition in Chinese historiography in the reform era. History and Theory 49: 336-360.

Lim, M. 2012. Laws, institutions and transboundary pasture management in the High Pamir and Pamir-Alai mountain ecosystem of Central Asia. Law, Environment and Development Journal 8(1): 45-58.

Markov, GE. 1978. Problems of social change among the Asiatic nomads. In The nomadic alternative, ed. W Weissleder, 305-311. The Hague: Mouton.

Markov, GE. 1981. Ausbeutungs- und Abhängigkeitsverhältnisse bei den Nomaden Asiens. In Die Nomaden in Geschichte und Gegenwart, ed. L Stein, 13-21. Berlin: Akademie-Verlag.

McMillen, DH. 2009. China, Xinjiang and Central Asia - 'glocality' in the year 2008. In China, Xinjiang and Central Asia. History, transition and crossborder interaction into the 21st century, ed. C Mackerass and M Clarke, 1-20. London, New York: Routledge.

Miller, D. 2000. Tough times for Tibetan nomads in western China: Snowstorms, settling down, fences, and the demise of traditional nomadic pastoralism. Nomadic Peoples 4(1): 83-109.

Millward, JA. 2009. Positioning Xinjiang in Eurasian and Chinese history: Differing visions of the 'Silk Road'. In China, Xinjiang and Central Asia. History, transition and crossborder interaction into the 21st century, ed. C Mackerass and M Clarke, 55-74. London, New York: Routledge. 
Montero, RG, J Mathieu, and C Singh. 2009. Mountain pastoralism 1500-2000: An introduction. Nomadic Peoples 13(2): $1-16$

Nori, M, and J Davies. 2007. Change of wind or wind of change? Climate change, adaptation and pastoralism. The World Initiative for Sustainable Pastoralism. Nairobi: IUCN.

Oi, JC. 1999. Two decades of rural reform in China: An overview and assessment. The China Quartely 159: 616-628.

Ostrom, E, T Dietz, N Dolšak, PC Stern, S Stonich, and EU Weber (eds.). 2002. The drama of the commons. Washington DC: National Academy Press.

Ptackova, J. 2011. Sedentarisation of Tibetan nomads in China: Implementation of the nomadic settlement project in the Tibetan Amdo area; Qinghai and Sichuan Provinces. Pastoralism: Research, Policy and Practice 1:4.

Robinson, S, and M Whitton. 2010. Pasture in Gorno-Badakhshan, Tajikistan: Common resource or private property? Pastoralism 1(2): 198-217.

Roe, E, L Huntsinger, and K Labnow. 1998. High reliability pastoralism. Journal of Arid Environments 39(1): 39-55.

Salzman, PC (ed.). 1980. When nomads settle: Processes of sedentarization as adaptation and response. New York: Praeger.

Salzman, PC, and JG Galaty. 1990. Nomads in a changing world: Issues and problems. In Nomads in a changing world, ed. PC Salzman and JG Galaty, 3-21. Naples: Instituto Universitario Orientale.

Schmidt, M, and A Doerre. 2011. Changing meanings of Kyrgyzstan's nut forests from colonial to post-Soviet times. Area 43(3): 288-296.

Scholz, F. 2008. Nomadism. A socioecological mode of culture. Ulaanbaatar: International Institute for the Study of Nomadic Civilizations.

Schütte, S. 2012. Pastoralism, power and politics: Access to pastures in northern Afghanistan. In Pastoral practices in High Asia. Agency of 'development' effected by modernisation, resettlement and transformation, ed. H Kreutzmann, 53-69. Dordrecht: Springer.

Scott, JC. 2009. The art of not being governed. An anarchist history of upland Southeast Asia. New Haven, London: Yale University Press.

Sheppard, E. 2012. Trade, globalization and uneven development: Entanglements of geographical political economy. Progress in Human Geography 36(1): 44-71.

Steimann, B. 2012. Conflicting strategies for contested resources: Pastoralists' responses to uncertainty in post-socialist rural Kyrgyzstan. In Pastoral practices in High Asia. Agency of 'development' effected by modernisation, resettlement and transformation, ed. H Kreutzmann, 145-160. Dordrecht: Springer.

Succow, M. 2004. Schutz der Naturlandschaften in Mittelasien. Geographische Rundschau 56(10): 28-34.

Svanberg, I. 1989. Turkistani refugees. In Ethnic groups in the Republic of Turkey, ed. PA Andrews, 591-601. Wiesbaden: Reichert.

Tapper, R. 2008. Who are the Kuchi? Nomad self-identities in Afghanistan. The Journal of the Royal Anthropological Institute 14(1): 97-116.

Vanselow, KA, T Kraudzun, and C Samimi. 2012. Land stewardship in practice. An example from the Eastern Pamirs of Tajikistan. In Rangeland stewardship in Central Asia. Balancing improved livelihoods, biodiversity conservation and land protection, ed. V Squires, 71-90. Dordrecht: Springer.

Xinchun, Z. 2011. Pastoralism in Xinjiang: Implementing the pastoralist settlement programme to promote sustainable development of pastoralism in Xinjiang. In Regional Workshop in Khorog and Kashgar. Pastoralism and rangeland management in mountain areas in the context of climate and global change, ed. H Kreutzmann, K Abdulalishoev, L Zhaohui, and J Richter, 182-188. Bonn: GIZ.

Yan, Z, N Wu, D Yeshi, and J Ru. 2005. A review of rangeland privatisation and its implications in the Tibetan plateau. Nomadic Peoples 9(1): 31-51.

Yeh, E. 2005. Green governmentality and pastoralism in western China: 'converting pastures to grasslands'. Nomadic Peoples 9(1): 9-29.

Yi, S, and E Sharma. 2009. Climate change and the Hindukush-Himalayan Rangelands. International Centre for Integrated Mountain Development, Information Sheet \#8/09. Kathmandu: ICIMOD.

Yi, S, M Ismail, and Z Yan. 2012. Pastoral communities' perspectives on climate change and their adaptation strategies in the Hindukush-Karakoram-Himalaya. In Pastoral practices in High Asia. Agency of 'development' effected by modernisation, resettlement and transformation, ed. H Kreutzmann, 308-322. Dordrecht: Springer.

doi:10.1186/2041-7136-3-7

Cite this article as: Kreutzmann: The tragedy of responsibility in High Asia: modernizing traditional pastoral

practices and preserving modernist worldviews. Pastoralism: Research, Policy and Practice 2013 3:7.

\section{Submit your manuscript to a SpringerOpen ${ }^{\mathcal{O}}$} journal and benefit from:

- Convenient online submission

Rigorous peer review

- Immediate publication on acceptance

- Open access: articles freely available online

- High visibility within the field

- Retaining the copyright to your article

Submit your next manuscript at $>$ springeropen.com 